\title{
KAPASITAS ADAPTASI KOMUNITAS PESISIR PADA KONDISI RAWAN PANGAN AKIBAT PERUBAHAN IKLIM (KASUS SEBUAH KOMUNITAS NELAYAN DI JAWA BARAT)
}

\section{(Adaptive capacity of coastal community to food insecurity due to climate change- a case of village in West Java)}

\author{
Nurmala K. Panjaitan*), Galuh Adriana, Ratri Virianita, Nanda Karlita, Renita Intan Cahyani \\ Departemen Sains Komunikasi dan Pengembangan Masyarakat, Fakultas Ekologi Manusia, Institut Pertanian Bogor \\ ${ }^{*}$ E-mail: nurmala_katrina@yahoo.co.id
}

\begin{abstract}
Climate change provokes various problems on coastal community's life such as reduction in the quantity and quality of the catch, sea-water flood, storms, tidal waves, and drought. Many impacts of climate change will not lead to the vulnerability of coastal communities when a community has sufficient adaptive capacity. The purpose of this study was to analyze the adaptive capacity of coastal communities to food insecurity as the impacts of climate change. Mix method approach such as survey, in-depth interviews, focus group discussions and observation was applied to collect the data. The unit analysis was community level ( $n=100$ poor fishery households, beneficiaries of government's poor rice program). The adaptive capacity of communities to food insecurity is relatively low due to low institutional memory, unable to conduct innovative learning and especially the lack of connectedness with others outside the community. There is no Collective action to cope with food insecurity due to poverty, community's culture and lack of local leadership.
\end{abstract}

Keywords: Climate change, adaptive capacity, coastal community, food insecurity

\begin{abstract}
ABSTRAK
Perubahan iklim menimbulkan banyak masalah pada kehidupan komunitas pesisir seperti penurunan kualitas dan kuantitas tangkapan, rob, badai, gelombang pasang dan kekeringan. Berbagai dampak perubahan iklim tidak akan menyebabkan kerentanan komunitas pesisir bila komunitas itu mempunya kapasitas adaptasi yang memadai. Tujuan penelitian ini adalah menganalisa kapasitas adaptasi komunitas nelayan untuk melihat kesiapan komunitas dalam menghadapi kerawanan pangan akibat perubahan iklim. Pendekatan survei, wawancara mendalam, focus group discussion, dan observasi digunaan untuk mengumpulkan data. Unit analisa adalah pada tingkat masyarakat dengan sumber data 100 rumahtangga nelayan miskin yang merupakan penerima program raskin. Kapasitas adaptasi masyarakat terhadap kerawanan pangan tergolong rendah karena rendahnya institutional memory, tidak mampu melakukan innovative learning dan kurangnya connectedness terutama dengan pihak lain di luar komunitas. Aksi kolektif dari komunitas untuk mengatasi kerawanan pangan tidak ada yang disebabkan oleh kemiskinan,budaya komunitas dan kurang berfungsinya kepemimpinan lokal.
\end{abstract}

Kata kunci: Perubahan iklim, kapasitas adaptasi, pantai komunitas, kerawanan pangan

\section{PENDAHULUAN}

Indonesia adalah salah satu dari 10 negara yang paling rawan bencana di dunia berdasarkan penelitian dari Center for Research on the Epidemiology of Disaster (CRED) (FSVA 2015). Bencana alam merupakan faktor utama kerawanan pangan transien di Indonesia. Pada tahun 2012 dan 2013 terjadi 15.432 bencana dan 3 provinsi yang paling sering terkena bencana adalah berturutturut Jawa Tengah, Jawa Barat dan Jawa Timur, khususnya bencana angin topan, banjir, tanah longsor dan kekeringan (Dewan Ketahanan Pangan 2015). Indonesia tidak hanya menghadapi bencana dalam skala besar dan tiba-tiba tetapi juga bencana yang dapat diprediksi akibat perubahan iklim. Perubahan iklim menjadi ancaman besar bagi ketahanan pangan dan gizi terutama bagi rumahtangga yang sangat tergantung pada produksi pertanian termasuk nelayan. Iklim yang tidak menentu, penyimpangan curah hujan, peningkatan resiko hama tanaman membawa dampak negatif bagi petani sehingga mereka sulit menentukan kalender pertanian dan berdampak pada menurunnya produksi dan produktifitas tanaman yang akhirnya mengancam mata pencaharian petani secara keseluruhan. Sedangkan kekeringan, banjir dan tanah longsor akibat curah hujan yang tinggi intensitasnya akan berdampak pada kerusakan lahan, menurunnya produksi dan produktifitas serta memburuknya kerawanan pangan yang ada.

Perubahan iklim dapat terlihat dari berbagai fenomena alam yang semakin sering terjadi saat ini seperti intensitas hujan yang tinggi, hujan disertai banjir, meningkatnya suhu udara dan musim yang tidak teratur. Laporan Intergovermental Panel on Climate Change (IPCC) ke-5 tahun 2014 mengungkapkan bahwa suhu telah meningkat sekitar $0,8^{\circ} \mathrm{C}$ dan akan terjadi peningkatan suhu ratarata sebesar $3^{\circ}-5^{\circ} \mathrm{C}$ pada akhir abad ini yang akan berdampak pada musnahnya beragam spesies flora maupun fauna (Pusat Informasi Perubahan Iklim Kementerian PU 2014). Sementara itu permukaan laut global telah mengalami kenaikan $20 \mathrm{~cm}$ selama periode 1901-2010 yang menimbulkan fenomena banjir, banjir rob, erosi pantai dan perendaman. Sementara itu sebanyak $3 \%$ dari karbon dioksida yang dihasilkan melalui kegiatan manusia diserap oleh laut sehingga terjadi keasaman laut dan peningkatan temperature laut yang menyebabkan berkurangnya populasi ikan dan makin menjauhnya area tangkapan (fishing area). Pemanasan global juga mengakibatkan menurunnya ekosistem pesisir dan laut yang akan berdampak pada kesejahteraan masyarakat 
pesisir yang hidupnya tergantung pada sumberdaya laut, seperti berkurangnya ketersediaan pangan dan air, peningkatan kemiskinan, dan munculnya berbagai masalah sosial al. Dengan demikian perubahan iklim membawa resiko besar bagi keamanan pangan global, kesehatan manusia dan pembangunan ekonomi terutama di wilayah pesisir.

Perubahan iklim di Propinsi Jawa Barat ditunjukkan oleh pola curah hujan yang berubah pada 2 dekade terakhir (1991-2007), berdasarkan data dari Global Precipitation Climatology Centre (GPCC). Awal musim kering bergeser dari bulan Juni ke bulan Juli dan akhir musim kering bergeser ke bulan November. Sedangkan curah hujan pada bulan September-Desember lebih rendah dari rata-rata 90 tahun sebelumnya sedang curah hujan bulan April-Juni lebih tinggi dari rata-rata 90 tahun sebelumnya (Suriadi 2010). Perubahan ini akan berdampak pada produksi dan produktifitas pertanian di Jawa Barat. Perubahan ekosistem laut akibat perubahan iklim menyebabkan berubahnya aktivitas penangkapan ikan melalui perubahan musim ikan dan kekacauan musim angin. Kekacauan ini menyebabkan menurunnya perolehan ikan, nelayan sulit menentukan waktu yang tepat untuk melaut dan peningkatan resiko melaut yang berdampak pada penurunan pendapat nelayan. Pendapatan nelayan yang menurun dapat mengakibatkan terjadinya rawan pangan akibat adanya rawan daya beli dimana nelayan tidak mempunyai cukup uang untuk memenuhi kebutuhan pangan keluarganya (Patriana dan Satria 2013)

Peta Ketahanan dan Kerentanan Pangan (FSVA) tahun 2015menampilkan masih ada 10,91 \% penduduk Jawa Barat yang hidup di bawah garis kemiskinan. Sementara itu jumlah rumahtangga Pra sejahtera di Jawa Barat(BPS 2015)menunjukkan dari 12.404.178 rumahtangga masih ada $19.27 \%$ yang tergolong rumahtangga pra sejahtera. Sedangkan Peta Kerawanan Pangan Jawa Barat mengungkapkan bahwa dari 5.245 desa di Jawa Barat masih ada 2500 desa atau $47.66 \%$ yang masuk kategori rawan pangan. Dengan kondisi masih cukup banyaknya desa yang tergolong rawan pangan apakah masyarakat pedesaandi JawaBarat dapat bertahan menghadapi berbagai gangguan lingkungan akibat terjadinya perubahan iklim saat ini?Perubahan iklim yang tengah terjadi dapat meningkatkan jumlah rumahtangga rawan pangan di Jawa Barat karena rumahtangga miskin adalah kelompok yang paling rawan (vulnerable) pada gangguan dari lingkungan fisik terutama bila gangguan tersebut datang berulangkali. Menurut Adger (2006) sensitivitas (sensitivity), terpaan (exposure)pada gangguan atau external stress dan kapasitas adaptasi (adaptive capacity) menentukan kerentanan (vulnerability) suatu sistim pada bencana. Kerentanan berhubungan dengan kelentingan komunitas (community resilience) tapi tidak selalu suatu komunitas yang rentantidak akan lenting (resilient).Komunitas pesisir dapat "bounce back"dengan cepat dari gangguan (lenting) ditentukan oleh kemampuan komunitas itu untuk menyerap gangguan sekaligus mempertahankan fungsi-fungsi pentingnya (Adger 2010). Untuk itu dibutuhkan ketersediaan sumberdaya (resource robustness) dan kapasitas adaptif komunitas untuk memanfaatkan dan mereorganisasikannya sedemikian rupa sehingga komunitasterjamin keberfungsiannya selama bencana maupun setelah bencana (Longstaff et.al. 2010). Bila keduanya berada pada tingkat yang tinggi atau salah satu tinggi dan yang lain rendah maka kelentingan komunitas bisa tercapai. Dengan demikian semakin besar kapasitas adaptasi komunitas maka akan semakin rendah kerentanannya. Akan tetapi kelentingan komunitas bersifat context-specific, dimanabesarnya sumberdaya dan kapasitas adaptasi dari masing-masing komunitas akan menghasilkan tingkat kelentingan komunitas yang berbeda. Tujuan penelitian ini adalah menganalisa kapasitas adaptasi komunitas nelayan untuk melihat kesiapan komunitas dalam menghadapi kerawanan pangan akibat perubahan iklim.

Komunitas adalah sesuatu kesatuan yang unik yang mempunyai kebutuhan lokal, pengalaman, sumberdaya dan ide-ide tentang tindakan pencegahan, perlindungan, respon dan pemulihan dari berbagai tipe bencana tersendiri. Setiap komunitas mempunyai akses pada sumberdaya dan kemampuan untuk memanipulasi dan mengambil keputusan yang tidak dimiliki oleh individu. Disamping itu ada saling ketergantung dan sistim interaksi yang dinamis antara manusia dan lingkungannya. Sumberdaya alam yang ada dalam komunitas selalu berkaitan dengan kelembagaan sosial, seperti kebiasaan, norma, aturan dan kelembagaan formal karenaitu dalam konteks perubahan iklim respon adaptif manusia sebaiknyadianalisa pada level komunitas (Adger 2000; Longstaff et al.2010; Maguire dan Cartwright 2008 ).

Komunitas pesisir mempunyai keunikan dibandingkan dengan komunitas lain yaitu ketergantungannya pada sumberdaya pesisir. Adger (2010) mengatakan ketergantungan pada sumberdaya adalah ketika tatanan sosial, mata pencaharian dan stabilitas suatu komunitas merupakan fungsi langsung dari produksi sumberdaya dan ekonomi lokal. Menurut Bailey dan Pomemy, yang dikutip Adger (2010) dalam konteks daerah pesisir di Asia, komunitas pesisir paling baik dipahami sebagai tergantung bukan hanya pada satu sumberdaya tetapi pada keseluruhan ekosistem. Sumberdaya pesisir bisa beragam dan semakin stabil ekosistemnya semakin lenting juga komunitas pesisir tersebut.

Dalam konteks perubahan iklim Gallopin (2006) menjelaskan bahwa kapasitas adaptif adalah kemampuan suatu sistim untuk menyesuaikan diri pada perubahan iklim (termasuk variabilitas iklim dan iklim yang ekstrim) agar dapat mengurangi kerusakan yang mungkin terjadi, memanfaatkan kesempatan-kesempatan atau agar dapat menghadapi konsekuensi yang terjadi. Kapasitas adaptasi juga adalah kemampuan komunitas menggunakan sumberdaya untuk melakukan perubahan dengan cara yang adaptif, reaktif dan proaktif. Ini yang membedakan respon system manusia dan sistim biologi dimana respon sistim biologi hanya reaktif saja. Kapasitas adaptasi komunits yang menyebabkan suatu komunitas beradaptasi pada saat dihadapkan pada bencana sehingga tetap dapat berfungsi walaupun ada beberapa bagian dari sistim yang mengalami perubahan atau penyesuaian ( Paton dan Johnston 2006; Maguire dan Cartwright 2008; Maxwell et al. 2013). Dengan demikian komunitas yang mampu mengenali dan memanfaatkan dengan positif berbagai sumber daya yang ada akan dapat mengembangkan mekanisme-mekanisme yang sesuai untuk dapat bertahan sebelum dan sesudah berbagai perubahan terjadi.

\section{METODOLOGI PENELITIAN}

Komunitas adalah suatu kesatuan yang mempunyai batas geografis yang sama dan berbagi nasib yang sama ( Norris et al. 2007; Longstaff et al. 2010). Selain mempunyai batas geografis dan kesamaan karakteristik, komunitas juga mempunyai identitas yang sama, komitmen, keterlibat dalam interaksi sosial dan ikatan psikologis diantara mereka dan dengan tempat tinggalnya (Kirmayer et al. 2009). Komunitas pedesaan memiliki karakteristik yang berbeda dari komunitas lainnya, yaitu memiliki latar belakang yang sama dengan tingkat pendidikan yang setara, afiliasi keagamaan dan etnik, juga rentang waktu masyarakat berada dalam komunitas tersebut (Kuliget et.al.2008). Pedesaan adalah suatu sistim sosial ekologi yang dibangun oleh berbagai komponen yang terdiri dari komponen ekologi, ekonomi dan sosial yang terkait sedemikian rupa sehingga menciptakan karakteristik yang khas pedesaan (Schouten et al. 2009). Daerah pedesaan yang umumnya hidup dari pertanian adalah daerah yang 
sering terekspos terhadap berbagai gangguan eksternal seperti bencana alammaupun gangguan sosial. Keterbatasan kapasitas yang dimiliki anggota komunitas pedesaan menjadikan mereka menjadi kelompok yang rentan ketika menghadapi perubahan ataupun goncangan dalam kehidupan.

Berdasarkan definisi di atas maka lokasi penelitian ini diambil di Dusun Tapak, sebuah dusunnelayan pada salah satu kecamatan yang termasuk dalam Kabupaten Karawang, Provinsi Jawa Barat. Pemilihan Kabupaten Karawang disebabkan berdasarkan data BPS (2015) masih ada 33,49 \% rumahtangganya yang tergolong rumahtangga pra sejahtera, apabila digabungkan dengan rumahtangga sejahtera 1 maka 58,24\% persen penduduk kabupaten ini masih tergolong miskin. Sebagian besar penduduk desa dimana Dusun Tapak berada hampir seluruhnya mempunyai mata pencaharian sebagai nelayan dan sebagian besar tergolong keluarga miskin (2773 kepala keluarga dari 2112 rumahtangga mendapat surat miskin dan $976 \mathrm{kk}$ mendapat kartu sehat/Jaringan Pengaman Sosial)dan sebanyak $50 \%$ kondisi bangunannya tidak permanen ${ }^{1}$. Anggota komunitas Penerima RASKIN (Program Beras untuk Keluarga Miskin) di komunitas ini ada 238 KK namun atas informasi kepala dusun yang benar-benar miskin hanya $145 \mathrm{KK}$ yang kemudian dijadikan kerangka sampling. Dengan teknik pengambilan sample simple random sampling terpilih $100 \mathrm{KK}$ sebagai responden.

Data yang dikumpulkan adalahdata primer dan data sekunder. Data primer diperoleh melalui pengisian kuesioner, observasi, wawancara mendalam (in-depth interview) dan diskusi kelompok terarah atau focused group discussion (FGD) yang dilakukan pada kelompok-kelompok sosial yang berbeda. Sedangkan data sekunder diperoleh dari berbagai dokumen dan data yang diperoleh dari BPS, Badan Ketahanan Pangan dan berbagai laporan yang berkaitan dengan lokasi penelitian. Analisis data menggunakan analisis deskriptif kuantitatif dan deskriptif kualitatif. Analisis deskriptif kualitatif dilakukan dengan reduksi data, penyajian data dan penarikan kesimpulan. Untuk menghindari kesalahan data dan kesalahan interpertasi digunakan pula metode triangulasi dimana data yang diperoleh dari informan yang satu dikonfirmasikan pada informan yang lain (Moleong 2002).

\section{HASIL DAN PEMBAHASAN}

Dusun Tapak terletak paling ujung dari Kabupaten Karawang dan tepat di tepi Laut Jawa. Jaraknya sekitar $7 \mathrm{~km}$ dari kecamatan atau $50 \mathrm{~km}$ dari Kabupaten Karawang.Untuk mencapai lokasi ini tidak ada angkutan umum, hanya ada mobil sewa dan ojek. Ongkos ojek dari kecamatan ke dusun cukup mahal yaitu Rp.20.000 sekali jalan. Kondisi jalan sangat buruk walaupun separuhnya sudah dicor dengan beton namun sisanya hanya tanah yang dikeraskan dan berlubang-lubang cukup besar sehingga sulit dilalui kendaraan terutama di musim hujan. Musim hujan biasanya terjadi antara bulan Desember- Maret sedangkan musim kemarau berkisar antara bulan April-November. Letaknya yang cukup sulit dijangkau membuat komunitas ini masih mencirikan desa namun dalam beberapa hal mulai menunjukkan sifat seperti masyarakat kota, berhubung letaknya masih berbatasan dengan kota Karawang dan Bekasi. Hampir seluruh anggota komunitas bekerja sebagai nelayan kecil dengan tangkapan utamanya udang dan rajungan, sisanya bekerja sebagai pedagang ikan asin, pembuat terasi atau buruh nelayan. Di sekitar komunitas ini banyak tambak-tambak bandeng namun yang besar-besar dimiliki oleh pengusaha dari luar Kabupaten Karawang,beberapa anggota komunitas hanya bekerja sebagai buruh saja di tambak itu. Di dekat dusun juga ada kawasan wisata Pantai Tanjung

1 Desa Tanjung Pakis dalam angka 2015, BPS Kabupaten Karawang
Pakis yang cukup banyak dikunjungi wisatawan lokal pada saat liburan walaupun untuk mencapai lokasi ini tidak mudah karena infrastruktur yang buruk. Anggota komunitas tidak banyak terlibat dalam kegiatan pariwisata, hanya beberapa orang yang berjualan ikan asin pada wisatawan.

Pendidikan anggota komunitas rata-rata SD dan jarang yang melanjutkan ke tingkat pendidikan lebih tinggi. Alasan utama orangtua tidak menyekolahkan anaknya adalah faktor biaya dan akses sekolah ke SMP dan SMA yang cukup jauh tidak mungkin dijangkau dengan jalan kaki, sementara ongkos ojek Rp.10.000 sekali jalan. Karena tidak bisa meneruskan sekolah, anak lakilaki umumnya membantu orang tua sebagai nelayan atau buruh nelayan, sementara anakperempuan cenderung dinikahkan pada usia muda.

Tidak semua nelayan dalam komunitas ini memiliki perahu, ada $41 \%$ nelayan yang tidak mempunyai perahu. Persentase ini masih sangat besar karena bagi nelayan, perahu merupakan alat transportasi yang sangat dibutuhkan agar dapat melaut. Nelayan yang tidak memiliki perahu menjadi anak buah kapal yang bekerja untuk juragan menerima upah sesuai dengan hasil penjualan tangkapan. Ukuran perahu nelayan beragam dari 6 hingga 7 meter dengan menggunakan mesin temple berkapasitas 10-16 PK.

Dalam 1 tahun terahir komunitas ini mengalami berbagai bencana, terutama paceklik ikan dan rob (lihat gambar 1). Sebagian besar responden (78 \%) menyebutkan paceklik ikan sebagai bencana utamayang saat ini tidak terduga kedatangannya dan berlangsung lebih panjang dari tahun sebelumnya. Sementara itu bencana rob,dimanaair laut menggenangi daerah pemukiman, walaupun hanya berlangsung 1-2 jam dan hanya setinggi mata kaki namun menyebabkan kerusakan pada rumah-rumahyang terletak di tepi lautyang sebagian besar belum permanen. Nelayan juga menyebutkan adanya bencana banjir yang diakibatkan meluapnya sungai yang bermuara tepat di pemukiman nelayan. Pada musim hujan air sungai akan meluap, membawa serta sampah dan lumpur yang menyebabkan pendangkalan sungai sehingga nelayan tidak dapat menyandarkan perahunya dekat pemukiman. Dulu 2 tahun sekali sungai harus dikeruk sekarang hampir setahun sekali hal itu harus dilakukan. Gelombang pasang dan badai di tengah laut juga dirasakan sebagai bencana bagi nelayan karena bisamenghanyutkan kapal bahkan dapat mengakibatkanresiko kematian bagi nelayan.

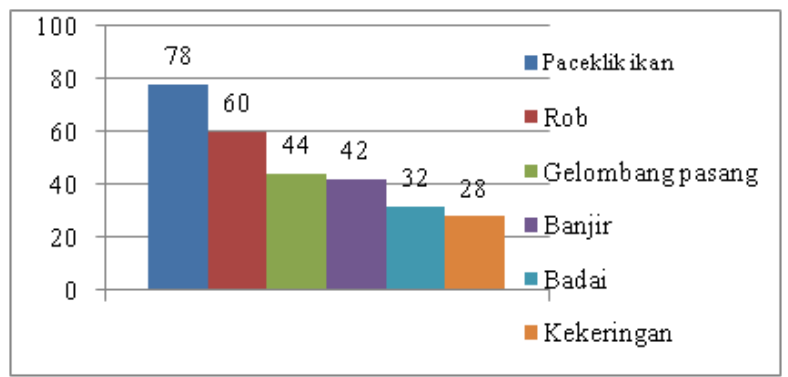

Gambar 1. Persentase Nelayan berdasarkan Bencana yang Terjadi dalam 1 Tahun Terakhir di Dusun Tapak,Tahun 2016

Pada gambar 2 tampak bahwa berkurangnya jumlah tangkapan akibat musim paceklik yang berkepanjangan dirasakan sebagai masalah oleh semua nelayan $(100 \%)$ demikian juga berkurangnya jenis tangkapan (82.0 persen). Masalah lainnya adalah tidak punya modal untuk melaut (78.0 persen), dimana untuk pergi melaut nelayan membutuhkan modal sedikitnya Rp. 


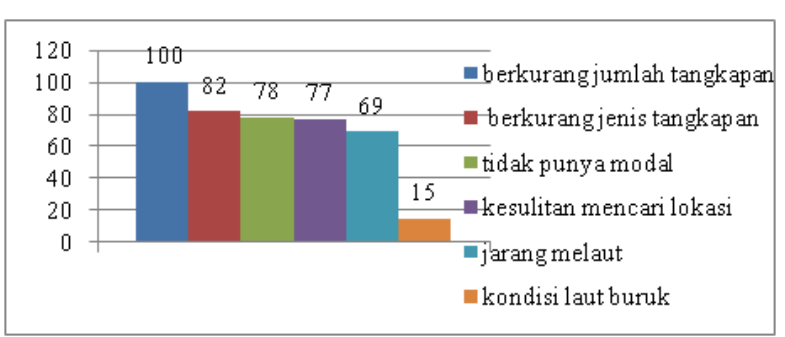

Gambar 2. Persentase Nelayan Berdasarkan Masalah yang Dihadapi, Dusun Tapak, Tahun 2016

100.000,- untuk membeli solar dan makanan untuk 3 orang ABK sebagai bekal ketika berada di laut. Nelayan juga mengalami kesulitan mencari lokasi penangkapan untuk mendapatkan ikan lebih banyak dan menghadapi kondisi laut yang buruk seperti adanya badai dan gelombang pasang di tengah laut. Masalah lainnya adalah jarang melaut akibat tidak adanya modal untuk melaut dan cuaca buruk dan masalah ketersediaan air tawar. Dusun Tapak merupakan dusun yang berbatasan langsung dengan laut, sehingga ketersediaan air bersih untuk minum dan keperluan sehari-hari menjadi sangat minim. Masalah kualitas air yang buruk sudah menjadi masalah kronis di dusun ini yaitu pada musim kemarau kondisi air menjadi asin sedang pada musim hujan menjadi payau sehingga tidak baik untuk dikonsumsi. Berhubung sudah menjadi bagian dari kehidupan sehari-hari maka nelayan tidak merasakan ini lagi sebagai masalah. Dengan demikian bagi nelayan perubahan iklim membawa dampak yang dapat dikelompokkan menjadi 4 yaitu : akses pada sumberdaya, keamanan, kemampuan meramalkan dan ketersediaan komoditas hasil laut (Berkes dan Jolly 2001)

Menurunnyaproduksidan produktifitasnelayaninimengakibatkan pendapatan nelayan jauh berkurang sehingga daya belinya juga menurun. Penurunan pendapatanmengakibatkankondisi kurang pangan pada sebagian besar nelayan miskin dalam komunitas karena $71 \%$ nelayan tidak punya uang untuk membeli bahan pangan. Pada gambar 3 tampak bahwa kondisi kekurangan pangan dalam 5 tahun terakhir dirasakan lebih dari satu kali oleh $59 \%$ rumahtangga nelayan, $21 \%$ mengalami 1 kali dan hanya $20 \%$ yang menyatakan tidak pernah mengalami kekurangan pangan. Sedangkan pada saat penelitian berlangsung $76 \%$ rumahtangga nelayan merasa kekurangan pangan, hanya $24 \%$ yang tidak kekurangan pangan. Ini berarti kondisi rawan daya beli menjadi penyebab kekurangan panganpada komunitas. Terbatasnya daya beli merupakan salah satu penyebab dari malnutrisi, yang menyebabkan pola makan yang tidak memadai, buruknya kesehatan dan kebersihan, terbatasnya pedidikan dan meningkatkan kerentanan rumah tangga terhadap malnutrisi.

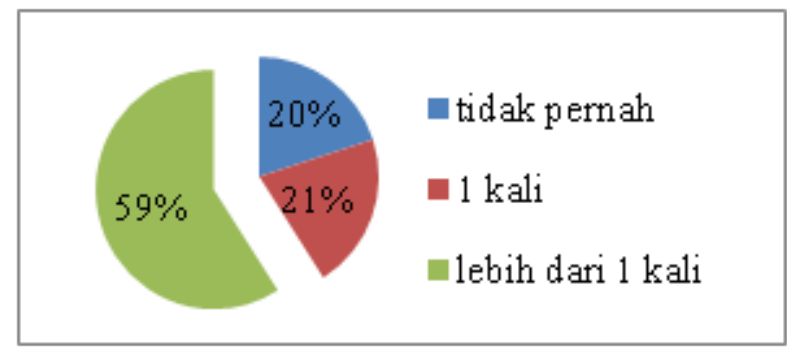

Kapasitas adaptasi dapat disebut juga sebagai kemampuan yang menyangkut berbagai sumberdaya baik fisik, kelembagaan, sosial, ekonomi, sarana, ketrampilan personal maupun atribut kolektif seperti kepemimpinan dan pengelolaan yang dimiliki komunitas untuk mengelola bencana (Bukle 2006). Besarnya kapasitas adaptasi akan menentukan kemampuan suatu system untuk beradaptasi yaitu memodifikasi atau merubah karakteristik atau tingkah lakunya untuk dapat mengatasi stress yang aktual atau yang diantisipasi (Brooks 2003). Adaptasi berbeda dengan kapasitas adaptasi, dimana adaptasi adalah penyesuaian dalam tingkahlaku dan karakteristik suatu system yang meningkatkan kemampuannya untuk mengatasi stres eksternal, atau suatu respon pada stressor(Maguire dan Cartwright 2008). Adaptasi juga tidak sama dengan coping, karena mekanisme coping lebih berupa sejumlah respon jangka pendek pada situasi-situasi yang mengancam sistim mata pencaharian dan sering berbentuk respon darurat pada musim yang tidak normal, Sedangkan strategi adaptasi berhubungan dengan variabel-variabel seperti nilainilai budaya yang lebih membutuhkan waktu untuk berubah, cara individu-individu, rumahtangga dan komunitas merubah aktifitas produktifnya dan memodifikasi aturan-aturan lokal dan kelembagaan untuk mengamankan mata pencahariannya (Berkes dan Jolly 2001).

Adaptasi adalah manifestasi dari kapasitas adaptasi yang dibentuk oleh kekuatan-kekuatan sosial, budaya, politik dan ekonomi (Smit dan Wandel 2006). Kekuatan-kekuatan ini tidak terpisah satu sama lain melainkan saling berhubungan. Kapasitas adaptif ada yang bersumber dari komunitas seperti jaringan kekerabatan yang kuat yang dapat menyerap stress, kehadiran pemimpin lokal, saluran komunikasi pada komunitas, dan kemampuan komunitas untuk mengorganisasikan diri dan ada juga yang bersumber dari sistim ekonomi dan sosial politik yang lebih umum seperti adanya program subsidi dari pemerintah (Smit dan Wandel 2006; Maguire dan Cartwright 2008.Longstaff et al. (2010) menyebutkan bahwa kapasitas adaptasi adalah fungsi dari kemampuan individu-individu dan kelompok-kelompok untuk:1) menyimpan dan mengingat pengalaman; 2) menggunakan ingatan dan pengalaman untuk belajar, berinovasi dan mereorganisasikan sumber-sumber dalam rangka menyesuaikan pada tuntutan lingkungan yang berubah; dan 3) berhubungan dengan orang lain di dalam maupun di luar komunitas uuntuk mengkomunikasikan pengalaman dan hasil belajar, self-organize atau reorganisasi saat tidak ada yang mengarahkan atau untuk mendapatkan sumberdaya yang ada di luar. Jadi dasar dari kapasitas adaptif pada tingkat komunitas adalah institutional memory, innovative learning dan connectedness. Institutional memory adalah akumulasi pengalaman dan pengetahuan lokal sebuah kelompok atau komunitas, yang dikumpulkan melalui pengamatan kelompok dan disimpan dalam berbagai cara seperti dokumen tertulis atau ritual-ritual dan upacara-upacara berulang yang dilakukan sejalan dengan keanggotaan kelompok

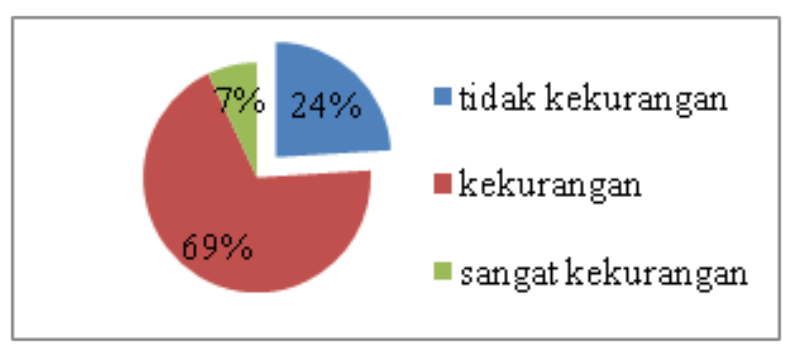

Gambar 3. Persentase Responden berdasarkan Frekuensi Kekurangan Pangan pada 5 Tahun Terakhir (kiri) dan Pada Saat Ini (kanan), Dusun Tapak, Tahun 2016 
yang berkembang sepanjang waktu. Selanjutnya kelompok atau komunitas mempunyai kemampuan mengunakan informasi dan pengetahuan yang dimilikinya untuk membuat adaptasi baru pada perubahan lingkungan atau menghindari mengulangi kesalahan di masa lalu, ini yang disebut sebagai Innovative learning. Difusi institutional memory dan innovative learning didukung oleh adanya keterhubungan interpersonal dan kelompok (connectedness). Tautan-tautan ini bisa merupakan jaringan sosial (informal) maupun jaringan organisasional (formal) atau modal sosial (Adger 2003). Jaringan-jaringan ini yang akan berkontribusi pada kemampuan komunitas untuk tukarmenukar, menyimpan dan memanggil kembali pengetahuan, dan mengambil tindakan kolektif dalam kondisi perubahan. Kuat dan lemahnya ikatan-ikatan ini akan menentukan kekuatan atau kerapuhan komunitas.Dengan demikian kapasitas adaptasi komunitas dalam menghadapi kekurangan pangan dapat dilihat dari pengetahuan dan pengalaman komunitas, kemampuan untuk memanfaatkan pengetahuan dan pengalaman tersebut dan jaringan hubungan antara anggota komunitas yang dimunculkan dalam aksi kolektif.

\section{Institutional Memory}

Komunitas ini sejak dulu hanya menggantungkan diri pada laut. Anggota komunitas hanya tahu menangkap hasil laut, membuat ikan asin dan merajut jaring. Kegiatan gesek ${ }^{2}$ biasanya hanya dilakukan oleh kaum perempuan khususnya istri nelayan yang memiliki perahu, tapi juga bisa dilakukan oleh istri nelayan ABK namun biasanya hanya ketika sang suami mendapat tangkapan ikan yang secara tak sengaja tersangkut pada jaringnya. Nelayan ABK atau buruh yang tak memiliki perahu untuk melaut, saat musim paceklik terjadi biasanya mengerjakan pekerjaan lain seperti nyudu ${ }^{3}$, dimana hasil tangkapannya biasanya dikonsumsi untuk kebutuhan sehari-hari rumahtangga. Banyak anggota komunitas juga terampil merajut jaring yang diperoleh secara turun menurun.Ketika nelayan ABK tidak melaut mereka merajut jaring baik untuk memperbaiki jaringnya sendiri maupun membuat yang baru untuk dijual. Perempuan juga ikut merajut jaring yang biasa dilakukan bersama-sama di sebuah rumah disela aktifitas mengurus rumahtangga.

Bahan pangan kecuali ikan diperoleh dengan membeli di warung. Sumber pangan lokal selain ikan tidak ada karena anggota komunitas merasa tidak punya modal untuk bertani atau beternak. Ada 2 orang anggota komunitas yang bertanam sayur-sayuran seperti labu panjang, labu parang dan timun apel namun keterampilan ini tidak diikuti oleh anggota komunitas lainnyapadahal selain dapat memenuhi kebutuhan sayuran bagi keluarga juga dapat dijual untuk menambah pendapatan. Bertanam sayuran dianggap membutuhkan biaya yang lumayan besar karena harus menguruk tanah dan menambahnya dengan tanah yang lebih subur dari tempat lain, sementara kondisi ekonomi nelayan dirasakan selalu kekurangan sehingga tidak punya modal untuk bertani.

Sementara itu pengetahuan komunitas tentang pangan seperti diversifikasi pangan dan cara mengolah makanan sudah didapatkan melalui sosialisasi dari Puskesmas, Posyandu dan Kader. Namun pengetahuan ini tidak merubah pola makan komunitas. Beras tetap menjadi makanan pokok walaupun mahal tetap dibeli, komunitas juga sering mengkonsumsi mie instantnamun sebagai lauk yang dimakan dengan nasi. Komunitas baru mengkonsumsi beras sejak tahun 1966, sebelumnya mereka

2 Gesek adalah kegiatan membelah ikan asin menjadi 2 bagian untuk kemudian dijemur dan dikonsumsi atau dijual. Biasanya pekerjaan gesek ini dilakukan oleh perempuan.

3 Nyudu adalah kegiatan menjaring udang rebon yang dilakukan nelayan di pantai makan jagung dicampur beras burgur yang dikukus. Namun saat ini tidak ada lagi yang mengkonsums jagung selain karena jarang ada di pasarjuga harganya lebih tinggi daripada harga beras. Singkong dan ubi hanya dianggap sebagai makanan selingan saja dalam bentuk makanan gorengan yang dijual warung. Sayuran kurang disukai kecuali masakan sayur asam yang juga biasa beli di warung. Buah-buahan hampir tidak pernah dikonsumsi karena dianggap mahal.

Sebenarnya tangkapan utama nelayan pada komunitas ini udang dan rajungan namun kadang kala pada jaring terselip ikan, inilah yang dikonsumsi keluarga baik dalam bentuk segar ataupun sudah dibuat menjadi ikan asin. . Jenis ikan yang biasa didapat ketika melaut yaitu ikan gilingan, blanak, kembung. Biasanya ikan yang sering diambil untuk dikonsumsi adalah ikan kembung atau ikan yang sudah rusak (tidak lengkap bagian tubuhnya). Sedangkan udang dan rajungan ataupun kepiting yang terjaring lebih sering dijual karena harganya mahal. Protein hewani yang sering dikonsumsi (terutama pada musim panen) adalah telur dan daging ayam terutama bagi anak sekolah dan balita. Orang dewasa hanya sesekali saja mengkonsumsi daging ayam selain karena mahal juga kaum laki-laki kurang menyukainya. Ketika membeli ayam pun mereka hanya membeli bagian sayap, kepala dan ceker karena harganya relatif mahal. Daging sapi hampir tidak pernah dikonsumsi dan hanya diperoleh melalui pembagian hewan qurban pada saat Lebaran Haji dan kalau mendapat besekan dari orang yang punya hajatan.

Berdasarkan pengalaman hidupnya nelayan dan keluarganya tahu bahwa tidak sepanjang tahun laut menyediakan hasil tangkapan yang tinggi.Pada bulan Januari sampai Mei adalah musim panen (musim angin timur atau rejeh) dimana ikan lebih mudah didapat bahkan nelayan bisa melaut sampai 2 kali, pada saat subuh untuk menangkap udang dan malam hari untuk menebar jaring rajungan yang akan diambil hasilnya keesokan harinya Walaupun terkadang ada kondisi kosong di laut sekitar 2-3 hari, namun pada umumnya nelayan bisa mendapatkan hasil tangkapan sampai $50 \mathrm{~kg}$ udang dalam satu kapal dalam sekali keberangkatan. Di luar musim panen biasanya ikan yang didapat hanya cukup untuk memenuhi kebutuhan hidup sehari-hari saja bahkan sering tidak ada ikan sama sekali. Pada bulan Juni sampai September disebut panen kecil dimana jumlah ikan sudah mulai berkurang. Sedangkan musim paceklik (musim angin barat/ musim laib)yang berlangsung sekitar 3 bulan, dari bulan Oktober sampai Desember hasil melaut tidak menentu, dan tidak jarang pula nelayan pulang tanpa mendapatkan hasil sama sekali yang mengakibatkan pendapatan keluarga tidak menentu juga. Pada masa inilah daya beli komunitas sangat rendah sehingga tidak dapat memenuhi kebutuhan pangannya.

Komunitas nelayan ini masih percaya bahwa ada kekuatan yang berkuasa atas laut yang menentukan keselamatan nelayan dan keberlangsungan laut dan isinya sebagai sumber penghidupan nelayan. Oleh karena itu sebelum musim panen (rejeh), nelayan akan melakukan ritual di laut untuk 'karuhun'(penguasa laut) sebagai rasa syukur dan terimakasih telah menjaga populasi ikan di laut serta harapan agar mendapat banyak tangkapan ikan di musim panen. Sedangkan setelah musim panen diadakan "pesta laut" yang diawali dengan upacara ucapan syukur kepada yang maha kuasa atas laut karena telah memberikan kehidupan bagi nelayan,yang kemudian diikuti dengan ritual memotong kepala kerbau. Setelah itu seluruh perahu nelayan secara beriringan akan menunju ke tengah laut untuk membuang kepala kerbau tersebut. Setelah kembali ke darat, para nelayan akan makan bersama dan selanjutnya ada pementasan wayang kulit. Ritual itu telah dipercaya nelayan sebagai suatu cara untuk menjamin ketersediaan ikan di laut dan keselamatan mereka selama melaut. 
Selama ini komunitas nelayan mengetahui tanda-tanda akan datangnya musim paceklik, sebagian besar nelayan $(76,8 \%)$ dapat menyebutkan 2 tanda alam sedangkan sisanya (23.2\%) dapat menyebutkan lebih dari 2 tanda. Tanda alam yang diketahui sebagian besar nelayan yaitu kondisi laut tenang tidak ada ombak, angin bertiup perlahan dari arah barat, air laut bening di permukaan namun kotor di bagian bawah dan mulai berkurangnya jumlah dan jenis tangkapan. Demikian juga bila akan terjadi banjir kiriman dari sungai biasanya ditandai oleh air sungai yang menuju ke laut berwarna pekat hitam diiringi ombak kecil. Biasanya diantara mereka akan saling menginformasikan jika tanda-tanda ini mulai tampak. Sebaliknya pada saat gelombang pasang dimana ombak cukup besar, mereka percaya bahwa hasil tangkapan rajungan akan melimpah, sedangkan udang akan lebih sedikit diperoleh.

Dalam kalender nelayan bulan Mei sampai Juni termasuk "musim pinggiran" dimana nelayan bisa mendapatkan ikan walau hanya melaut beberapa kilometer dari muara atau bibir pantai. Sedangkan bulan Agustus-September mulai masuk "musim tengah" yaitu kondisi dimana para nelayan harus melaut hingga jauh dari bibir pantai untuk mendapatkan ikan yang mengakibatkan mereka bisa berada berhari-hari jauh dari dusunnya. Pengetahuan ini dibagi bersama anggota komunitas sehingga mereka tahu kapan, bagaimana cara dan dimana mereka akan mendapatan jumlah ikan yang banyak.Namun "kalender nelayan" ini mulai bergeser karena beberapa tahun belakangan ini hampir semua nelayan $(95 \%)$ mengamati bahwa musim paceklik terjadi dari bulan Januari sampai Juli dengan perkataan lain sampai bulan Juli tahun ini nelayan masih terus beradadimusim tengahpadahal seharusnya sudah masuk musim panen. Musim paceklik tahun ini dinilai sebagai yang paling parah yang pernah mereka alami. Dengan semakin panjangnya musim tengah bukan hanya nelayan semakin kehabisan modal kerja karena mereka harus mencari ikan lebih jauh dan berada lebih lama di laut, tapi juga berkurangnya ketersediaan ikan untuk pangan keluarga.Nelayan tidak jarang tidak membawa ikan untuk konsumsi keluarga pada saat paceklik sehingga kondisi kekurangan pangan tidak dapat dihindari.

Komunitas belum mempunyai cara lain dalam memanfaatkan sumberdaya laut sebagai alternatif nafkah misalnya dengan membuat kerajinan tangan dari kerang atau mengolah hasil laut menjadi makanan olahan. Peluang kerja dan usaha pada sektor pariwisata belum dapat dimanfaatkan untuk menambah pendapatan keluarga.

Minimnya keterampilan ini selain karena pendidikan yang rendah (rata-rata tamat SD) juga karena keterbatasan informasi yang disebabkan lokasi komunitas yang sulit dijangkau sehingga sumber informasi hanya dari sesama nelayan dan pegalaman sehari-hari dalam komunitas.

\section{Innovative Learning}

Kemiskinan akan mengurangi daya beli rumah tangga dan menyebabkan masyarakat menggunakan strategi penyelesaian masalah yang cenderung negatif yang dapat menambah kerentananpada status ketahanan pangan dan gizi.. Hampir semua nelayan dalam komunita Dusun Tapak sudah tinggal di tempat itu lebih dari 30 tahun dan rata-rata sudah menjadi nelayan selama lebih dari 18 tahun dan tentunya sudah berulangkali mereka mengalami musim paceklik dan berbagai tantangan alam seperti gelombang pasang maupun banjir rob. Mereka juga tahu tandatanda alam akan datangnya musim paceklik dimana hasil laut jauh berkurang. Namun komunitas tidak banyak mengembangkan kegiatan-kegiatan ekonomi yang dapat meningkatkan pendapatan keluarga. Komunitas tetap mengandalkan laut sebagai sumber pangan dan mata pencahariannamun terbatas pada usaha penangkapan udang dan rajungan saja. Anggota komunits yang melakukan pekerjaan lain di luar desa, biasanya sudah memiliki akses ke desa lain atau memiliki hubungan kerjasama dengan orang lain diluar desa. Tapi, secara umum anggota komunitas tidak mau meninggalkan desa dan tidak ingin melakukan pekerjaan lainnya. Ketika sedang musim paceklik, nelayan lebih memilih berdiam diri di rumah, membetulkan jaring, membuat jaring baru, atau memperbaiki dan membersihkan kapal daripada mencari pekerjaan lainnya.Upah yang diperoleh dari membuat jaring adalah sebesar Rp. 20.000 per hari. Ada juga istri nelayan yang menjual ikan asin, baik dengan cara mengolah ikan asin sendiri lalu menjualnya maupun membeli ke orang lain lalu menjualnya. Ada juga istri nelayan yang menjadi pedagang keliling menjual lauk dan sayuran matang, buah-buahan potong, dan lain-lain. Akan tetapi hanya beberapa saja istri nelayan saja yang melakukan kegiatan ekonomi kebanyakan hanya mengurus rumahtangga saja dengan alasan tidak ada modal berdagang dan masih repot mengurus anak-anak.

Hanya ada beberapa modifikasi yang dapat dikatakan sebagai mekanisme coping bukan strategi adaptasi (Berkes dan Jolly 2001) dimana nelayan hanya melakukan tindakan reaktif bukan adaptif dan proaktif (Gallopin 2006). Ketika udang dan rajungan mulai sulit didapat nelayan pergi ke lokasi penangkapan yang lebih jauh ( hingga ke Kepulauan seribu di Provinsi DKI dan ke Sumatera) namun hal ini hanya dilakukan bila cuaca baik karena angin dan gelombang laut yang terlalu tinggi beresiko kapal pecah dan tewasnya nelayan. Untuk menghindari kejadian yang tidak diinginkan semua nelayan mempuanyai surat izin untuk melaut dan kartu nelayan yang menjadi tanda pengenal nelayan. Nelayan yang mempunyai kapal mengurangi frekuensi melaut dan jumlah ABK yang dibawauntuk mengurangi modal melaut dan pembagian hasil tangkapan, atau bergabung dengan nelayan lain untuk berbagi modal melaut walaupun hal itu jarang juga terjadi. Sedangkan nelayan yang tidak mempunyai kapal (ABK/anak buah kapal) mengatasi kekurangan pendapatan dengan pindah ke juragan lain, beberapa menjadi supir ojek ataupun buruh bangunan di kota. Inovasi yang dilakukan terbatas pada modifikasi jaring yang dapat mencegah udang yang ditangkap terlepas lagi. Jaring dibuat menjadi 2 lapis (pengarang dan daging) ${ }^{4}$ dan ditambahkan baluh sebagai pelampung atas yang menahan jaring supaya tetap mengapung dan juga timah gendang serta timah panjang sebagai pemberat agar jaring tetap bertahan di air. Dengan alat ini jaring tidak mudah robek dan tangkapan menjadi lebih banyak, tak jarang nelayan juga mendapatkan rajungan dan ikan-ikan kecil terselip pada jaring tersebut. Rajungan bukan merupakan komoditas pilihan utama karena harga jualnya masih di bawah udang, yatu sekitar Rp.25.000-Rp.30.000 sementara udang bisa mencapai Rp.70.000- Rp.100.000/kg. Semua nelayan dalam komunitas telah memanfaatkan jaring modifikasi ini.

Demikian juga dalam hal pangan meskipun nelayan sudah mengetahui akan datang musim paceklik dan mereka akan mengalami rawannya daya beli namun tidak ada aksi proaktif di tingkat rumahtangga maupun tingkat komunitas untuk menabung atau membangun persediaan makanan. Masalah pangan dianggap urusan domestik tiap rumahtangga dan hampir semuanya (98\%) tidak melakukan persiapan apapun dengan alasan mereka tidak punya uang. Tidak adanya persiapan rumahtangga ini diduga karena sebagian besar dari mereka memang tidak mempunyai kemampuan menyimpan uang. Anggota komunitas cenderung boros, sehingga apa yang didapatkan hari ini dihabiskan pada hari ini juga. Penyimpan makanan hanya dapat dilakukan beberapa

4 Pengarang adalah istilah nelayan untuk jaring bagian luar yang mempunyai ketebalan dan diameter lubang yang lebih besar. Daging adalah jaring bagian dalam yang ketebalan dan diameter lubangnya lebih kecil, yang bahan dasarnya bisa dari benang (retiles) atau dari plastik/kenur (tilek). 
orang saja dengan jumlah terbatas. Hanya sedikit (14\%) yang melakukan persiapan dengan memakai tabungan di bank, mencari pekerjaan lain atau menjadi ABK di juragan lain. Pada musim paceklik komunitas juga kesulitan mendapat air tawar sehingga hampir setiap hari harus membeli dengan harga Rp10.000 per jerigen. Sedangkan untuk keperluan mandi dan mencuci warga komunitas bersama-sama menaruh gentong-gentong besar di depan rumah untuk menampung air hujan.

Penyelesaian masalah tidak ada modal untuk melaut atau memenuhi kebutuhan pangan sehari-hari lebih banyak dilakukan oleh anggota komunitas dengan mekanisme coping negatif yaitu dengan berhutangbaik pada juragan atau "bos" dengan memanfaatkan hubungan patron-klien, maupun pada kelembagaan keuangan formal seperti bank maupun yang tidak formal seperti rentenir. Berhutang bahan pangan di warung lebih sering dilakukan untuk keperluan melaut yang disebut 'nendo'. Biasanya warung sudah paham dengan kondisi nelayan dan tetap memberikan pinjaman hutang kepada nelayan untuk "pesangon" maupun utnuk memenuuhi kebutuhan hidup sahari-hari.Namun patron yang dalam hal ini jurangan besar yang mempunyai banyak kapal umumnya tidak mau meminjamkan uang untuk keperluan konsumsi pangan, melainkan hanya untuk "pesangon", modal melaut atau modal usaha lain seperti warung. Karena itulah nelayan terkadang berbohong seolah-olah meminjam uang untuk memperbaiki mesin padahal untuk membeli bahan pangan rumahtangga. Meminjam pada tetangga atau kerabat jarang dilakukan karena merasa sama-sama tidak punya uang kecuali pada musim panen dimana uang berlebih selain digunakan untuk membayar utang, membeli emas untuk tabungan juga kadangkadang dipinjamkan pada tetangga.

Pada gambar 4 tampak bahwa pada saat daya beli sangat rendah cara yang umum dilakukan anggota komunitas adalah berhutang ke warung (64\%) dan memilih makanan yang lebih murah (52 $\%)$, sedangkan usaha lainnya adalah mengurangi porsi makan (43\%), mencari ikan atau menunggu mendapat bantuan dari anggota komunitas lainnya (keluarga atau tetangga).

Pada komunitas nelayan istri menjadi orang yang paling bertanggung jawab menyediakan pangan keluarga. Meskipun suami kembali ke rumah tanpa membawa uang atau hasil tangkapan istri tetap menyediakan nasi dengan lauk seperti tempe, ikan asin, sambal atau mie instant, ini yang dimaksud memilih makanan yang lebih murah. Karena biasanyapara istri lebih banyak memenuhi lauk pauk keluarga dengan membeli jajanan di warung atau pedagang keliling seperti pisang goreng, nasi uduk, mie bakso, sayur sop, orek tempe, semur tahu, sayur asem, sayur labu panjang, sayur bayem dan jagung, terutama pada musim panen. Warung di sekitar komunitas selain menjual bahan

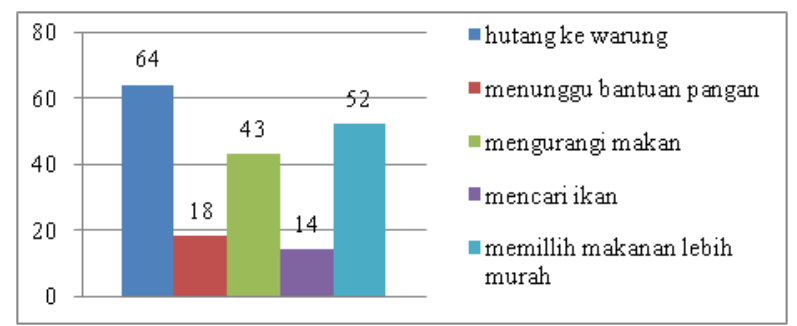

Gambar 4. Persentase Rumahtangga berdasarkan Usaha yang Dilakukan pada Saat Kekurangan Pangan pangan mentah juga menjual makanan masak seperti nasi uduk, goreng pisang/ubi, bermacam sayuran berkuah. Perilaku membeli ini dilakukan dengan alasan lebih hemat, irit dan praktis daripada memasak sendiri karena akan membutuhkan biaya yang cukup tinggi untuk gas, minyak goreng, dan bahan masakan lainnya. Hampir semua rumahtangga di lingkungan informan melakukan hal yang demikian. Pada musim paceklik membeli makanan matang tetap dilakukan hanya jenis dan jumlahnya berkurang. Biasanya 1 porsi makanan matang dikonsumsi 4 orang walaupun ada yang hanya mendapat kuah masakan itu saja, yang biasa menjadi bagian dari ibu rumahtangga. Anak-anak juga sering jajan yang bisa menghabiskan biaya Rp.20.000-Rp.30.000 per hari pada musim panen, di musim paceklik berkurang menjadi Rp.5.000 - Rp. 10.000 per hari.

Mengurangi makan dilakukan keluarga di musim paceklik dengan membatasi banyaknya nasi yang dikonsumsi oleh keluarga yaitu sekitar 1,5 liter beras untuk keluarga yang beranggotakan 4 orang danmengurangi lauk. Pada awal musim paceklik biasanya nasi dikonsumsi dengan mie instan yang dicampur dengan telur. Minggu berikutnya hanya mengkonsumsi mie saja dan mingguminggu selanjutnya ketika uang semakin menipis keluarga hanya mengkonsumsi ikan asin itupun minta kepada keluarga dan tetangga yang sering membuat ikan asin. Dalam kondisi yang sangat sulit, biasanya keluarga mengkonsumsi nasi dan kerupuk, atau nasi dan garam, atau bubur. Program pembagian RASKIN (beras untuk keluarga miskin) berubah menjadi "rasta" (beras merata) melalui kebijakan dari Desa, karena raskindibagi secara merata. Setiap keluarga mendapatkan kupon untuk menebus beras sebanyak $5 \mathrm{Kg}$. Pembagian secara merata ini bertujuan mengurangi kecemburuan sosial diantara warga karena semua warga sebetulnya butuh membeli beras lebih murah namun pada sisi lain program ini tidak membantu keluarga yang memang benar-benar membutuhkan karena jatah mereka menjadi berkurang.

Untuk mendapatkan uang atau memenuhi kebutuhan pangan terkadang istri nelayan melakukan barter barang-barang limbah dengan pengumpul barang rongsokan seperti gelas plastik bekas air kemasan, kardus, botol dan lainnya denganuang atau bahan pangan seperti ubi, singkong,mie instan atau yang lainnya seperti sabun, dan piring. Tukang yang mengumpulkan barang bekas tersebut datang setiap 1 minggu sekali.Setiap pengumpul barang rongsokan mempunyai ketentuan yang berbeda-beda perihal jenis barang yang bisa di-barter. Perilaku barter ini biasa dilakukan anggota komunitas baik pada musim laib maupun rejeh.

Dengan berbagai cara di atas ternyata lebih dari sebagian rumahtangga (59 \%) merasa berhasil mengatasi situasi rawan pangan pada saat musim paceklik.

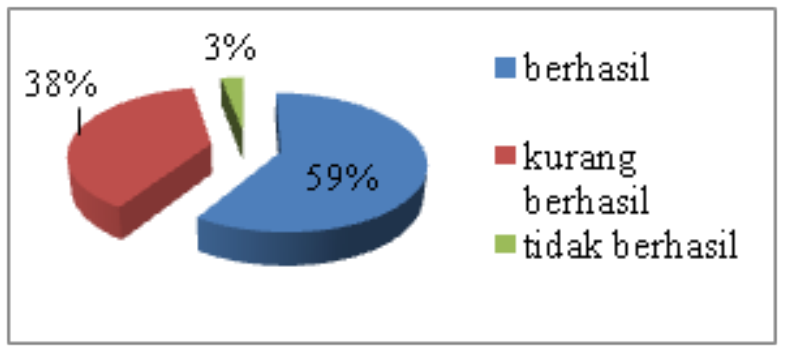

Gambar 5. Persentase Rumahtangga berdasarkan Keberhasilan Memenuhi Kebutuhan Pangan dalam Situasi Rawan Pangan 
Namun hasil observasi menunjukkan bahwa pola makan yang tidak memadai, buruknya kesehatan dan kebersihan, terbatasnya pedidikan dan meningkatkan kerentanan rumah tangga pada komunitas Dusun Tapak menyebabkan menurunnya kualitas kesehatan dan malnutri. Pada umumnya anggota komunitas menderita batuk pilek dan penyakit kulit seperti gatal-gatal dan korengan. Anak-anak cenderung bergizi buruk namun dusun tidak mempunyai data tertulis mengenai hal ini, hanya tampak bahwa anak-anak sering terserang batuk pilek, juga rambutnya tipis dan kemerahan.

\section{Connectedness}

Keterhubungan interpersonal dan kelompok pada komunitas Dusun Tapak lebih banyak dengan orang-orang dari dalam daripada dari luar komunitasnyadan lebih banyak bersifat interpersonal. Dalam definisi relasi sosial menurut Mignone dan O'Neil (2005) seperti yang dikutip Kirmayer et al.(2009) relasi sosial yang menonjol dalam komunitas ini adalah bonding relations atau intra-community connections. Bridging relation atau intra-community connections dan linkage relations atau hubungan antara komunitas dengan pemerintah, lembaga dan badan-badan lainnya tergolong rendah. Bridging relations komunitas hanya dengan pemerintah lewat bantuan beras Raskin, dengan pihak Puskesmas kecamatan, Bank pemerintah dan bank keliling atau rentenir yang selalu siap memberikan pinjaman uang. Peranan Komunitas hanya mengorganisir pembagian beras dari pemerintah tapi tidak mengorganisir keterhubungan komunitas sebagai kelompok dengan pemerintah sehingga tidak ada program-program bantuan yang dapat menambah ketrampilan atau membangun innovative learningbagi anggota komunitas. Hubungan dengan kelembagaan keuangan formal (bank dan koperasi nelayan) maupun informal (bank keliling dan rentenir) juga lebih bersifat hubungan interpersonal dan terbatas pada peminjaman uang saja.

Bonding relations di dalam komunitas dalam hal ekonomi melibatkan hubungan antara nelayan dengan pemilik warung dan juragan/bos/tengkulak yang mau memberikan hutang juga dengan tetangga dekat yang terkadang saling memberi pinjaman uang atau makanan pada saat-saat tertentu. Tetapi kedekatan dengan tetangga terbatas dengan tetangga yang rumahnya berdekatan baik yang masih ada ikatan keluarga maupun tidak, sedangkan dengan yang rumahnya agak jauh jaraknya meskipun masih ada hubungan keluarga jarang saling membantu karena ada rasa malu jika diketahui tidak punya makanan.

Keterhubungan interpersonal dengan beberapa pihak dalam komunitas ternyata menimbulkan beberapa masalah bahkan berpotensi konflik dan dapat menghambat nelayan untuk dapat keluar dari kemiskinannya. Hal ini disebabkan oleh keterhubungan antara nelayan dengan "juragan" atau tengkulak atau "bos" mengakibatkan nelayan tidak dapat memanfaatkan kelembagaan ekonomi dalam komunitas (Koperasi Nelayan Bahari) yang dapat memberi bantuan modal melalui programprogram dariKementrian Kelautan dan Perikanan. Diantara 110 perahu yang ada di Dusun Tapak, hanya ada 7 nelayan yang menjadi anggota tetap dari koperasi tersebut. Adanya hubungan patron-klien antara tengkulak dan nelayan, membuat nelayan tak bisa bergabung dengan koperasi karena memiliki hutang yang tidak pernah selesai dengan "juragan" atau tengkulak atau "bos"-nya. Sementara banyak bantuan baik dari pemerintah maupun swasta yang masuk ke dalam komunitas tersebut, harus melalui koperasi yang telah berbadan hukum tetap. Hal tersebut seringkali menimbulkan kecemburuan sosial dan kesalah pahaman antara sesama nelayan karena nelayan anggota koperasi dapat mengakses bantuan berupa pinjaman modal, sementara nelayan yang bukan anggota koperasi tidak mendapatkan akses tersebut.Nelayan bukan tidak ingin menjual hasil tangkapannya ke koperasi, namun karena ikatan patron-klien antara nelayan dengan tengkulak, nelayan tidak bisa serta merta menjual hasil tangkapannya ke koperasi karena nelayan wajib menjual tangkapannya kepada "bos"/ tengkulak/juragan yang telah meminjamkan mereka uang selama ini sehingga mereka bisa memiliki perahu untuk melaut. Harga jual pada tengkulak lebih rendah dari koperasi. Contohnya, $1 \mathrm{~kg}$ rajungan dibeli koperasi dengan harga Rp. 21.000,- sementara tengkulak hanya membelinya Rp. 17.000,-. Demikian juga $1 \mathrm{Kg}$ udang jika di jual ke koperasi akan dibeli dengan harga Rp. 75.000,- sedangkan di tengkulak atau bos hanya Rp. 70.000,-.

Melalui kegiatan simpan pinjam sebagai anggota koperasi, nelayan dapat menabung sekaligus bisa mendapatkan pinjaman untuk keperluan nelayan. Selain itu, nelayan yang menjadi anggota koperasi wajib menjual hasil tangkapannya kepada koperasi. Koperasi akan berfungsi sebagai penjaga harga, sehingga tengkulak tidak bisa secara sewenang-wenang menekan harga jual kepada nelayan seperti yang selama ini terjadi. Koperasi akan melelang/ menjual hasil tangkapan nelayan di Tempat Pelelangan Ikan (TPI), yang dapat dibeli oleh siapa saja, termasuk oleh tengkulak. Dengan demikian, melalui koperasi pendapatan nelayan dapat meningkat sekaligus, dapat membantu mereka saat musim paceklik terjadi. Namun sepertinya hal tersebut masih jauh dari harapan, jeratan hutang tengkulak dan hutang pada rentenir yang mencekik nelayan terlanjur membuat mereka tak bisa berbuat banyak. Sebanyak apapun bantuan yang diberikan pemerintah untuk nelayan, selama ikatan "balas budi" dalam hubungan patron-klien belum bisa di hilangkan, maka hal tersebut akan sia-sia. Penguatan kelembagaan ekonomi melalui koperasi nelayan ini baru bisa dilakukan secara efektif, ketika nelayan lepas dari belitan hutang. Koperasi nelayan Bahari baru mampu membebaskan 7 orang nelayan dari tengkulak dengan menebus/ membayarkan hutang mereka sebesar Rp. 150.000.000,- yang berasal dari bantuan swasta, sehingga butuh kurang lebih uang sebesar Rp. 2 Milyar jika akan membebaskan 110 kapal nelayan yang berada dalam komunitas Dusun Tapak ini.

Bonding relationsjuga menghasilkan aksi kolektif untuk membangun sarana kepentingan umum seperti membangun masjid dan jalan serta membantu keluarga yang kemalangan (meninggal atau sakit) serta untuk mengadakan acara pesta laut tahunan, suatu ritual nelayan yang diyakini akan menjamin keselamatan dan keberhasilan usaha nelayan.Akan tetapi untuk memecahkan masalah kekurangan pangan akibat perubahan iklim ini tidak ada aksi kolektif yang dilakukan oleh anggota komunitas. Menurut Tompkins dan Adger (2003) aksi kolektif adalah salah satu solusi untuk mengelola sumberdaya, dengan kerja bersama diantara komunitas dan bekerja sama dengan pemerintah maka komunitas dapat mengatasi perubahan iklim dengan lebih baik. Tidak adanya aksi kolektif dalam hal pangan dalam komunitas Dusun Tapak selain disebabkan oleh kemiskinan juga disebabkan hal-hal lainnya sepertibudaya komunitas dankurang berfungsinya kepemimpinan lokal untuk memobilisasi komunitas ( CLES 2013).

Budaya komunitas Dusun Tapak yang tergolong kolektif mendorong adanya tuntutan konformitas yang tinggi dan beban untuk perduli atau bertanggung jawab pada orang lain (Kirmayer et al. 2009). Kebiasaan keluarga untuk berhutang daripada mencari sumber pendapatan lain dan kebiasaan membeli makanan matang daripada membuat sendiri dan membiarkan anak-anak untuk mengkonsumsi makanan jajanan pabrik merupakan bentuk konformitas dalam komunitas. Meskipun ada beberapa orang yang melakukan tindakan adaptif dan proaktif untuk mengatasi 
daya beli yang rendah dengan berdagang dan menanam sayuran namun komunitas tidak terdorong untuk menirunya. Rasa perduli dan tanggung jawab yang besar pada orang lain pada budaya komunitas membuat anggotanya menahan diri untuk meminta bantuan karena kuatir membebani anggota lainnya dan menimbulkan dampak negative pada hubungan diantara mereka. Oleh karena itu anggota komunitas lebih memilih berhutang pada warung atau rentenir daripada meminta tolong atau berhutang pada anggota komunitas lainnya meskipun pada umumnya masih mempunyai hubungan kekerabatan.Akibatnya keluarga nelayan semakin terlibat dalam hutang yang tidak pernah terselesaikan. Kepemimpinan lokal cenderung tidak terlalu berperan dalam membangun saling percaya di antara warga komunitas.

Kapasitas adaptif yang rendah ini menyebabkan komunitas Dusun Tapak tidak terlalu berhasil beradaptasi pada kondisi kerawanan pangan. Daya beli komunitas tetap rendah karena tidak memiliki sumber nafkah alternatif pada musim paceklik dan kurang keterampilan serta kurang kemauan untuk melakukan pekerjaan lain dan keluar dari komunitasnya. Dalam skala penilaian 1-10 kebanyakan nelayan menilai kehidupan mereka pada masa lalu dan masa sekarang tetap berada pada nilai 5 atau sedang-sedang saja. Seorang nelayan mengatakan kalau dulu nelayan tinggal di rumah bilik, tapi tanpa hutang. Sekarang tinggal di rumah yang lebih bagus, berlantai keramik dan berdinding baru bata tapi memiliki banyak hutang dan terikat pada "bos". Harga ikan dikendalikan oleh bos (karena punya hutang) sehingga selalu dibawah harga pasar dan nelayan tidak berbuat bisa berbuat apa-apa. Keadaan seperti ini membuat kondisi nelayan semakin sulit dan kualitas hidupnya menurun yang ditandai dengan banyaknya(77 \%) nelayan mengaku anggota keluarganya sering sakit terutama anak-anak dan remaja.

\section{KESIMPULAN DAN SARAN}

Kapasitas adaptasi nelayan dalam aspek instutional memory dapat dikatakan sangat terbatas karena nelayan hanya memiliki pengetahuan lokal sebatas pekerjaan sebagai nelayan saja, pengetahuan atau ketrampilan lain di luar pekerjaan itu tidak dimiliki. Kemiskinan, pendidikan yang rendah dan rendahnya connectedness atau bridging relationsturut berperan dalam keterbatasan instutional memory yang mengakibatkan komunitas ini kurang mampu membuat adaptasi baru (Inovative learning) pada perubahan lingkungan atau menghindari mengulangi kesalahan di masa lalu. Meskipun mereka mengetahui adanya perubahan iklim yang menyebabkan tidak menentunya musim dan berkurangnya tangkapan di laut, namun mereka tetap melakukan kebiasaan-kebiasaannya dalam mencari nafkahyang saat ini tidak lagi mencukupi kebutuhan keluarga. Tidak ada aksi kolektif dari komunitas nelayan untuk membuat aktifitas nafkah yang baru yang adaptif terhadap perubahan iklim sekaligus dapat memberikan penghasilan yang lebih tinggi.

Dalam menghadapi masalah kerawanan pangan tidak ada aksi kolektif dalam komunitas yang disebabkan oleh kemiskinan, budaya kolektifitas dan kurang berfungsinya kepemimpinan lokal dalam komunitas yang mampu memobilisasi komunitas untuk membangun sumber pangan lokal dan mengubah pola makan yang lebih adaptif dan lebih sehat. Bonding relations dalam komunitas walaupun intensitasnya tinggi namun kurang mampu membangun aksi kolektif dalam mengatasi situasi rawan pangan di dalam komunitas. Hubungan patron-klien membatasi akses nelayan pada kelembagaan ekonomi yang dapat memberi solusi pada kurangnya modal usaha dan daya beli untuk memenuhi kebutuhan pangan keluarga.Budaya komunitas yang menuntut konformitas yang tinggi membuat anggota komunitas tidak dapat mengaplikasikan pengetahunnya tentang cara-cara baru yang lebh sehat dalam pola makan keluarga.

\section{DAFTAR PUSTAKA}

[BPS], 2016. Kabupaten Karawang dalam Angka. Badan Pusat Statistik Kabupaten Karawang.

[BPS], 2016. Propinsi Jawa Barat dalam Angka. Badan Pusat Statistik Propinsi Jawa Barat.

Adger WN, 2000. Social and Ecological Resilience: Are They Related?. Progress in Human Geography 24, 3(2000) pp 347-364

Adger WN, 2003. Social Capital, Collective Action and Adaptation to Climate Change. Global Environmental Change 16(2006) pp 268-281. Dapat diunduh dari: https:// www.jstor.org/stable/30032945

Adger WN, 2006. Vulnerability. Global Environmental Change. 16: 268-281 Dapat diunduh dari: https://www. coastalcluster.curtin.edu.au/local/docs/Resilience/ Adger $\% 202006$ CS

Adger WN, 2010. Climate Change, Human well-being and Insecurity. New Political Economy 15 (2) 275-292.

Badan Ketahanan Pangan Daerah, 2014,Mendukung Komitmen Jawa Barat sebagai Provinsi Bebas Rawan Pangan (diakses tanggal 30 April 2014 Dapat diunduh dari: http:// bkpd.jabarprov.go.id/mendukung-komitmen-jawa-baratsebagai-provinsi-bebas-rawan-pangan/)

Bukcle P. 2006. Chapter 6 Assessing Social Resilience. Dalam Douglas Paton dan David Johnston, 2006. Disaster Resilience: An Integrated Approach. Charles and Thomas Publisher, Ltd Springfield, Illinois, USA

Berkes F dan Jolly D, 2001. Adapting to Climate Change: SocialEcological Resilience in A Canadian Western Arctic Community. Conservation Ecoloty 5(2) URL: http:// www.consecol.org/vol5/iss2/art18

Center for Local Economic Strategis (CLES). 2014. Community Cohesion and Resilience - Acknowledge the Role and Contributing of Housing Providers. Final Report to Housing Diversity Network

Dewan Ketahanan Pangan, Kementerian Pertanian dan World Food Programme (WFP). 2015. Peta Ketahanan dan Kerentanan Pangan Indonesia 2015. Dapat diunduh dari: dari: https://www.wfp.org/content/indonesia-foodsecurity-and-vulnerability-atlas-2015

Gallopin GC.2006. Linkages between vulnerability, resiliene and adaptive capacity. Global environmental change 16(2006). Global environmental change. www.elsevier. com/locate/gloenvcha

Kirmayer LJ, Sehdev M, Whitley R, Dandeneau SF, Isaac C, 2009. Community Resilience: Models, Metaphors and Measures. Jurnal de la santé autochtone. National Aboriginal Health Organization (NAHO).

Kulig JC, Edge DS, Joyce B, 2008. Understanding Community Resiliency in Rural Communities Through Multimethod Research. Jurnal of Rural and Community Development 3,3 (2008) pp 74-99.

Longstaff PH, Armstrong NJ, Perrin K, Parker WM, Hidek MA, 2010. Building Resilient Communities: A

Maguire B dan Cartwright S, 2008. Assessing a Community's Capacity to Manage Change: A Resilience Approach to Social Assessment. Australian Goernment Bureau of Rural Sciences. Commonwealth of Australi 2008. Dapat diunduh dari www.tba.co.nz/tba-eq/Resilience approach. pdf

Norris HF, Stevens SP, Pfefferbaum B, Wyche KF, dan PfefferbaumRL, 2007. Community Resilience as a Metaphor, Theory, Set of Capacities, and Strategy for Disaster Readiness, Am J. Community Psychology 
$41: 127-150$

Patriana R dan Satria A, 2013. Pola Adaptasi Nelayan Terhadap Perubahan Iklim: Studi Kasus Nelayan Dusun Ciawitali. Desa Pamotan. Kecamatan Kali Pucang, Kabupaten Ciamis. Jurnal Sosial Ekonomi Kelautan dan Perikanan Vol. 8 No.1 tahun 2013

Preliminary Framework for Assessment. Homeland Security Affairs, Volume VI, No.3. www. HSAJ.ORG

Schouten M, Van Der Heide M, Heijman W. 2009. Resilience of Social Ecological Systems in European Rural Areas: Theory and Prospects. [Prociding Seminar]. Makalah disampaikan pada The 113 EAAE seminar; 9-11 Desember 2009; Republic of Serbia

Smit B dan Wandel J, 2005. Adaptation. Adaptive Capacity and
Vulnerability. Global Environmental Change 16 (2006) 282-292. Dapat diunduh dari: www.uio.no/studier/emner/ annet/sum/SUM4015/h08/Smit.pdf

Suriadi AB, 2010. Perubahan Iklim dan Ketahanan Pangan di Jawa Barat. Globe volume 12 No 1 Juni 2010

Tim Mitigasi dan Adaptasi Perubahan Iklim PU, 2014. Laporan kajian ke-5 IPCC Pokja Basis Ilmiah. Pusat Informasi Perubahan Iklim Kementrian PU. Dapat diunduh dari: dari https://mapipu2013.wordpress.com

Tim Mitigasi dan Adaptasi Perubahan Iklim PU, 2014.Laporan kajian ke-5 IPCC dan Dampaknya pada Indonesia Dapat diunduh dari: https://mapipu2013.wordpress. com/2014/12/29/laporan-ipcc-ke-5-dan-dampaknyapada-indonesia/ 